\title{
Influence of Perceived Organisational Justice and Organisational Climate on Job Performance Among Secondary School Teachers in Makurdi Metropolis of Benue State
}

\author{
Chinelo Helen Ogwuche ${ }^{1, *}$, Mikailu Habiba Musa ${ }^{1} \&$ Joe Nyam $^{1}$ \\ ${ }^{1}$ Department of Psychology, Benue State University, Makurdi, Nigeria \\ *Correspondence: Department of Psychology, Benue State University, Makurdi, Nigeria. E-mail: \\ chineloogwuche@gmail.com
}

Received: March 28, $2018 \quad$ Accepted: April 17, $2018 \quad$ Online Published: April 23, 2018

doi:10.5430/mos.v5n2p34 URL: https://doi.org/10.5430/mos.v5n2p34

\begin{abstract}
The study investigated influence of perceived organisational justice and organisational climate on job performance among secondary school teachers in Makurdi metropolis. A total of 188 secondary school teachers were drawn from Makurdi metropolis. The findings revealed that 106 (56.4\%) were males and 79(42.0\%) were females. The study used three standardized instruments which include (i) Organisational justice scale was developed by Nerinhoff and Moorman (1993), Organizational climate questionnaire developed by DeCottis and Koys (1991) and Job Performance Scale developed by Goodman and Svyantek (1999). Results from the hypotheses tested showed that perceived organizational justice significantly influence job performance. $[\mathrm{F}(3,182)=64.222, \mathrm{P}<.001]$. The result also indicated that organizational climate did not significantly influence job performance among secondary school teachers $[\mathrm{F}(1,181)=.003, \mathrm{P}>.05$. The result finally showed that perceived organizational justice and organizational climate significantly and jointly influence job performance $[\mathrm{F}(4,181)=50.131, \mathrm{P}<.001$. Based on the findings of the study, it was recommended among others that, the government through the ministry of education should organise seminars to enlighten school management officials on the important roles played by perceived organisational justice and job performance among teachers thus provide adequate working environment for proper leaning.
\end{abstract}

Keywords: perceived organisational justice, organisational climate and job performance

\section{Introduction}

To grow and thrive in today's competitive environment, the government, educational institutions, and businesses need to continue to provide enabling working environment, devoid of very stressful conditions (Ambrose \& Schminke, 2009). Institutions and businesses invest a great deal of resources in employment tests, job interviews, and training programs in an attempt to increase motivation, build human capital, and ultimately improve the job performance of employees. The measurement process of individual level job performance consists of many parts including defining and measuring job performance (Pilo, 2013).

Job performance can be defined as "all the behaviours employees engage in while at work" (Jex, 2002). More commonly, job performance refers to how well someone performs at his or her work. Initially, researchers were optimistic about the possibility to define and measure job performance (Cekmecelioglu, 2006).

A fair amount of the employees' behaviour displayed at work is not necessarily related to job-specific aspects. Historically, there have been three approaches to explain the dimensions of job performance: as a function of outcomes; as a function of behaviour; as a function of personal traits (Celik, 2012). The majority of the studies have shifted their focus on defining job performance in terms of outcomes and behaviour, since these are easier and more objective to define and to observe personal traits (Hersen, 2004). From an employee's point of view job performance is essentially the result of a series of behaviours. The various tasks performed on a daily basis contribute to job performance in general (Cardy, 2004). In this line of thought Jex (2002) developed an influential model containing eight dimensions to measure job performance and they are: i, Job-specific task proficiency: behavior related to core tasks of the job. ii, Non-job-specific task proficiency: general work behavior. iii, Written and oral communication 
task proficiency. iv, Demonstrating effort: level of commitment to core tasks. v, Maintaining personal discipline. vi. Facilitating peer and team performance. vii, Supervision/Leadership. viii, Management/Administration (Jex, 2002).

From a supervisor's perspective, on the other hand, outcomes are the key elements for job performance appraisal. After all, at the end of the day results are more important to an employer than the activities leading to those results (Cardy, 2004). However, employee's job performance plays a significant role in any organisation achievement and competency (Yong-ki \& sally, 2015). The impact of organizational justice perceptions on job performance is believed to stem from equity theory. This would suggest that when people perceive in justice they seek to restore justice. One way that employees restore justice is by altering their level of job performance. Procedural justice affects job performance as a result of its impact on employee attitudes. Distributive justice affects job performance when efficiency and productivity are involved, Justice perceptions improve productivity and performance Dawson, Abbott \& Shoemaker (2011)

Hellriegel, Slocum, \& Woodman (2001) found a relationship between organisational justice and job performance among employers. According to Obeidi, (2012) Perceived organisational justice refers to the overall fairness of the organisation reward system and the perceived fairness of the actions of individuals responsible for implementing the rewards allocation system. Masterson, Lewis, Goldman \& Taylor (2000), found that perceived organisational justice was positively correlated with organisational climate. It is obvious that when teachers in a secondary school perceived that they are being treated fairly by the school management and environment, their level of job performance moves up the ladder. This means that the ability of the school authority to expose teachers to activities that make them feel fairly treated is likely to create a sense of work performance and satisfaction in such an employee. This will motivate employees to commit more to the organisation.

Organisational justice is a key factor associated with the success of every organization. In order to keep employees satisfied, committed, and loyal to the organization, the organization needs to be fair in its system regarding distributive justice, procedural justice, and interactional justice. When employees feel that they are treated fairly by the organization in every aspect, they are inclined to show more positive attitude and behaviours like job performance. Issues like allocating monetary resources, hiring employees in organizations, policy making and policy implications that affect decision maker and the people who are affected from such decisions require special attention in respect of justice (Colquitt, Greenberg, \& Zapata-Phelan, 2005).

Organizational justice is considered a fundamental requirement for the effective functioning of organizations. Fairness perceptions holds an important position in the decisions and processes as per human resource aspect (Thurston \& McNall, 2010; Jawahar, 2007; Cohen-Charash \& Spector, 2001) such as pay, benefits and other compensation facets. In actual fact, fairness in compensation received, decisions regarding the compensation-related process and the way this information is communicated to all the employees hold an integral role in formulating the responses about the compensatory system (Nelson, Smith, Greer \& Duke, 2008; Milkovich \& Newman, 2008).

Organizational justice is an essential component and predictor of successful organizations. Organization that is fair and just in its procedures, policies, interactions and distribution systems, employees of that organization give better response to the organization (in terms of their positive behaviours and productivity). Enhancing organizational justice resulted in improved outcomes from employees. Managers should take actions to improve employees' job performance and organizational commitment so to decrease employees' turnover intension with the help of distributive and procedural justice (Elanain, 2009). Cropanzano, Ambrose \& Greenberg, (2007) argue that organizational justice has the potential to create powerful benefits for organizations and employees alike include greater trust and commitment. Organizational justice refers to people's perception of fairness in organizations, consisting of perceptions of how decisions are made regarding the distribution of outcome (distributive justice) and the perceived fairness of those outcomes themselves (as studied in equity theory) (Greenberg \& Baron, 2003). Equity has generally been conceptualized in terms of perceived fairness and operationalized as a three dimensional construct: distributive, procedural and interactional justice (Wat \& Shaffer, 2005). The word equity connotes feelings of good, just, right and fair, and they are deeply embedded in our common heritage.

Distributive justice concern people's perceptions of the fairness of the distribution of resources between people (Greenberg \& Baron 2003). It's also refers to the perceived fairness of the amounts of compensation employee receive (Alwan, (2007). Therefore, distributive justice perspective focuses on the fairness of the evaluations received relative to the work. Cropanzano, Ambrose \& Greenberg, (2007) distinguish three allocation rules that can lead to distributive justice if they are applied appropriately: equality (to each the same), equity (to each in accordance with contributions), and need (to each in accordance with the most urgency). Distributive justice is concerned with the reality that not all workers are treated alike; the allocation of outcome is differentiated in workplace (Cropanzano, 
Ambrose \& Greenberg, 2007). Karsh, Bookse, \& Sainfort, (2005) also found that employee may rationalize their desire to quit by finding 'evidence' which illustrates how unfairly rewards are distributed. Furthermore, distributive justice seems to play a salient role for employee in evaluating their employing organization (Loi, Borman, Ilgen \& klimoski, 2006). Employee would be more attached to their organization if they cannot obtain the same benefits in another firm (Lee, Griffin, Neal, Neale, 2007).

Past research demonstrates that procedural justice often is more predictive of a variety of work attitudes, including organizational commitment (Warner, Dunnette \& Hough, 2005). The fairness of the decision making process itself seems to be more important than the actual amount of compensation that is received by individual (Teprstra \& Honoree 2003). Cropanzano, Prehar, and Chen (2005) argued that, although procedural justice and interactional justice are distinct constructs, they are closely correlated. As pointed out by Tyler and Bies (2004), procedural justice is important in shaping interpersonal contexts, and thus it affects perception of interaction justice. Cropanzano, Ambrose \& Greenberg, (2007) argued that fair process lead to intellectual and emotional recognition, thus in turn, creates the trust and commitment that build voluntary cooperation in strategy execution. This, procedural justice perspective focuses on the fairness of the evaluation procedures used to determine ratings (Kumar \& Giri, 2007). If the process is perceived as just, employees show greater loyalty and more willingness to behave in an organizational best interest (Cropanzano, Ambrose \& Greenberg, 2007). employee's direct or indirect perception of the work environment such as perceived autonomy, trust on mangers, teamwork/cohesion, rewards/recognition and perceived fairness can be tress down to the kind of justice system the organization relay on Storey (2011).

Studies have shown that organizational climate is also a correlate of job performance. Organizational climate quality is widely thought of as an essential determinant of job performance, and job satisfaction (Unal, 2012). Jing, Avery, \& Bergsteiner, (2011) Organizational climate includes management or leadership styles, participation in decision making, provision of challenging jobs to employees, reduction of boredom and frustration, provision of benefits, personnel policies, and provision of good working conditions and creation of suitable career ladder for academics. These characteristics should be suitable to engender the productive capacities of employees and bring about higher level of commitment and performance to the organization. This is vital to our understanding of organizational justice and climate on job performance (Kallestad, 2010). However, the aim of management is to create a climate that is supportive of hard-work and high productivity throughout the organization. Organizational climate has been described as an employee's direct or indirect perception of the work environment, the general attitude or feeling; an atmosphere, condition or a situation which exists in an organization which embodies characteristics such as: structure, responsibility, reward, risk, warmth, support, standards, conflict and identity in the organization (Kessel, Hannemann-Weber \& Kratzer, 2012). Jing, Avery, \& Bergsteiner, (2011) enumerated the characteristics of a healthy organizational climate to include the gains of integration and performance to the goals of the organization from which comes the willingness to change. Therefore, a favourable work environment will engender higher levels of performance and productivity. It is against this background that this study is designed to investigate perceived organisatioal justice and organisational climate on job performance among secondary school teachers in Makurdi Metropolis.

\section{Statement of the Problem}

Job performance is considered an important factor in the recruitment and retention of employees in addition to the productivity and quality of services provided by them. However, there seems to be a general consensus among researchers that Job performance of secondary school teachers in Nigeria is declining. This has led to the incessant strikes and poor teaching performance among teachers which have become a worrisome scenario because it lead to poor students performance in school. This has a tendency to affect parents' satisfaction with teaching and learning, leading to reduction in the quality of perfection. The result has been a constant class between teachers and their employers, leading to low performance on the part of the teachers.

Many studies have been found in the research literature on Job performance and related factors among secondary school teaches, however, no such studies conducted in Benue State, specifically Makurdi metropolis that linked perceived organisational justice and organisational climate to job performance It is in view of the above that the researcher wishes to investigate the influence of perceived organisational justice and organisational climate on job performance among secondary school teachers in Makurdi. 


\section{Purpose of the Study}

The purpose of this study is to examine perceived organizational justice and organizational climate on job performance among secondary school teachers in Makurdi metropolis. Therefore, the study aimed at determining (1) the influence of Perceived organisational justice (distributive, procedural and interactional) on job performance among secondary school teachers. (2) Influence of Organisational climate on job performance among secondary school teachers. (3) joint influence of Perceived organisational justice (distributive, procedural and interactional) and organisational climate on job performance among secondary school teachers in Makurdi Metropolis. Hypotheses were tested based on the three specific purposes of the study.

\section{Method}

\subsection{Research Design}

The study adopted the cross-sectional survey design on perceived organisational justice and organisational climate on job performance among secondary school teachers in Makurdi Metropolis in using questionnaires. Cross-sectional survey is an observational study; it is the collection of information from respondents at a single period in time using questionnaire, snap-shot or recorder. This type of design utilizes different groups of people who differ in the variable of interest. The study design is appropriate because it allows the researcher to compare many variables at the same time and no active manipulation would be performed on any of the variables. It also allows for the sampling of opinions, feelings, attitudes and interest of the respondents.

\subsection{Setting}

The research was conducted in Makurdi Metropolis among secondary school teachers. Makurdi the state capital was established in the early twenties and gained prominence in 1927 when it became the headquarters of the then Benue Province. Samples were drawn from secondary school teachers selected from five functional government and private schools in Makurdi metropolis.

\subsection{Participants}

The participants for this study were 188 secondary school teachers in Makurdi metropolis with mean age of 13.0811 $(\mathrm{SD}=8.98845)$. They comprised of $106(56.4 \%)$ male and $79(42.0 \%)$ female, $3(1.6 \%)$ did not indicate their age. Teachers cadre; Senior 64(34.0\%), Junior 77(41.0\%), Causal 44(23.4\%) and 3(1.6\%) did not indicate. Going by their religion 159(84.6\%) were Christians, 20(10.6\%) were Islam, 5(2.7\%) were traditional, 4(2.1\%) did not indicate their religion. Marital status was sampled as: $45(23.9 \%)$ who were single, 114(60.6\%) married, $12(6.4 \%)$ divorced, 14(7.4\%) widowed and $3(1.6 \%)$ did not indicate. Teachers educational qualification was sampled as; NCE 30(16.0\%), HND 18(9.6\%), OND 11(5.9\%), Degree 100(53.2\%), and 29(15.4\%) did not indicate their qualification. Length of service was also sampled as: 16(8.5\%) 1year, 16(8.5\%) 2years, 15(8.0\%) 3years, 17(9.0\%) 4years, $35(18.6 \%)$ 5years, $15(8.0 \%)$ 6years, $8(4.3 \%)$ 7years, $8(4.3 \%)$ 8years, $14(7.4 \%)$ 9years, $5(2.7 \%)$ 10years, $6(3.2 \%)$ 12years, 16(8.5\%) 13years, 2(1.1\%) 15years, 4(2.1\%) 17years, 4(2.1\%) 18years, $7(3.7 \%)$ 20years. Finally the teachers schools were sampled as; 27(14.4\%) were from Tilley Gyado College, 26(13.8\%) UBE North Bank, 15(8.0\%) Government Girls' College Makurdi, 33(17.6\%) Mount Saint Gabriel's', 27(14.4\%) Anglican Secondary School, 23(12.2\%) Ecwa Secondary School, 14(7.4\%) Government Model Secondary School Makurdi, 10(5.3\%) Christ Anglican secondary School high level, and 13(6.9\%) Teachers model school. All the schools sampled in this study were within different axis of Makurdi Metropolis.

\subsection{Sampling}

Polit and Hunger (1995) stated that sampling is the process of selecting a portion of the population to represent the entire population. Convenience sampling technique was used for this study. Most studies conducted used stratified sampling technique and simple random sampling technique because of the nature of the population of study and the behavioural pattern of the profession that they are more on ground than what obtains. But for this study, convenience sampling technique was used because not everybody would be around as such whoever is around completes the questionnaire. To achieve this aim, the sample frame was drawn from secondary school teachers selected from five functional government and private schools in Makurdi metropolis. In addition, samples were drawn on male and female teacher's junior and senior cadre from these schools. The researcher went from one school to another and from office to office to administer the questionnaire and whoever that is in office or on seat and agreed to complete the questionnaire were selected as one of the sample size. 


\subsection{Instruments}

The study made use of the following instrument: Organisational Justice Scale (C) Organizational Climate Questionnaire (D) Job Performance Questionnaire.

Organisational Justice Scale: Organisational justice scale was developed by Nerinhoff and Moorman (1993). It has 20 items with a 5point likert's scale (1- strongly disagree, 2- disagree, 3- neutral, 4- agree, 5- strongly agree). The instrument has three subs scales. They are:
a. $\quad$ Distributive justice $=$ items $1-5$
b. $\quad$ Procedural justice $=$ items $6-11$
c. Interactional justice $=$ items $12-20$

The cronbachs alpha for distributive justice scale in western studies was 0.90 (Moorman \&Neinhoff, 1998). However, the conbach's alpha for procedural justice was 0.79 and 0.90 for interactional justice (1993).

Organizational Climate Questionnaire: Organizational climate questionnaire is a 25 item scale developed by DeCottis and Koys (1991) which measures organizational climate on a 5-point rating scale. It contains statements that describe participants' perception of the work environment such as: "I have independence for organizing my own work". Reliability: Reliability of the instrument $=0.77$ Validity: Validity of the instrument $=0.68$

Job Performance Scale: Developed by Goodman and Svyantek (1999) Job Performance Scale which consist of 25 items, covering three dimensions of Job Performance, i.e. Altruism, Conscientiousness and Task Performance. The first 16 items are related to Contextual Performance and altruism whereas remaining 10 items are related to Task Performance. The scale has a reliability coefficient of .89 with a respond format ranging from 1--Never; 2-Rarely; 3Sometimes; 4; Often; 5-Always.

\subsection{Procedure}

The researcher utilized one structured questionnaire for both male and female junior and senior cadre and was presented personally by the researcher to all respondents in the selected schools. Thus, this enhanced uniformity of response bearing in mind the degree of variations in perception of what the organizational justice and climate is. A structured questionnaire gives respondents a number of alternative options from which they must choose the one that best represent their view. The value of the study and the instructions were explained to the respondents. Respondents were requested to complete the questionnaires which were collected personally by the researcher from individual respondent and ensured a high return rate and encouraged freedom of expression from the respondents. A total of 250 copies of the questionnaire were distributed to respondents and they were debriefed in accordance with research ethics in Psychology. However only 188 copies were returned and valid for analysis.

Data for this study were analyzed using Simple Linear Regression and Multiple Regression to analyze the stated hypotheses. Simple linear regression was uses to test the influence of perceived organizational justice on job performance and the independent influence of organizational climate on job performance while Multiple Regression was used to test for joint influence of perceived organizational justice and organizational climate on job performance

\section{Results}

Hypothesis one stated that perceived organizational justice (distributive, procedural and interactional) will significantly influence job performance among secondary school teachers.

Table 1. Simple Linear Regression Showing Result for the Influence of Perceived Organizational Justice on Job Performance Among Secondary School Teachers

\begin{tabular}{|c|c|c|c|c|c|c|}
\hline Variables & $\mathrm{R}$ & $\mathrm{R}^{2}$ & $\beta$ & $\mathrm{F}$ & $\mathrm{t}$ & $\mathrm{P}$ \\
\hline Constant & .720 & .518 & & 64.222 & 5.131 & .000 \\
\hline Distributive & & & .105 & & 1.759 & .080 \\
\hline Procedural & & & .653 & & 10.991 & .000 \\
\hline Interactional & & & .088 & & 1.579 & .116 \\
\hline
\end{tabular}


The result in table 1 revealed that perceived organizational justice significantly influence job performance. $[\mathrm{F}(3,182)$ $=64.222, \mathrm{P}<.001]$. This result further showed that, perceived organizational justice (distributive, procedural and interactional) significantly accounted for $51.8 \%$ of the total variance in job performance among secondary school teachers. On their individual contribution the result revealed that, procedural justice $(\beta=.653, \mathrm{t}=10.991, \mathrm{P}<.001)$ made the highest contribution to the influence in job performance among secondary school teachers, distributive justice $(\beta=.105, \mathrm{t}=1.759, \mathrm{P}<.05)$ followed, while interactional justice $(\beta=.088, \mathrm{t}=1.579, \mathrm{P}>.05)$ did not make any significant contribution in the observed variance in job performance among secondary school teachers. Based on this finding, hypothesis one was only confirmed for distributive justice and procedural justice.

Hypothesis two stated that; organizational climate will significantly influence job performance among secondary school teachers.

Table 2. Simple Linear Regression Showing Result for the Influence of Organizational Climate on Job Performance Among Secondary School Teachers

\begin{tabular}{lllllll}
\hline Variables & $\mathrm{R}$ & $\mathrm{R}^{2}$ & $\beta$ & $\mathrm{F}$ & $\mathrm{t}$ & $\mathrm{P}$ \\
\hline Constant & .004 & .000 & & .003 & 8.955 & .000 \\
Organizational Climate & & & .004 & & .052 & .959 \\
\hline
\end{tabular}

The result in table 2 indicated that organizational climate did not significantly influence job performance among secondary school teachers $[\mathrm{F}(1,181)=.003, \mathrm{P}>.05$. with this result, hypothesis one was rejected and the null hypothesis upheld.

Hypothesis three stated that; perceived organizational justice and organizational climate will significantly and jointly influence job performance among secondary school teachers.

Table 3. Multiple Regression Showing Result for the Joint Influence of Perceived Organizational Justice and Organizational Climate on Job Performance Among Secondary School Teachers in Makurdi

\begin{tabular}{lcccccc}
\hline Variables & $\mathrm{R}$ & $\mathrm{R}^{2}$ & $\beta$ & $\mathrm{F}$ & $\mathrm{t}$ & $\mathrm{P}$ \\
\hline Constant & .729 & .531 & & 50.131 & 5.127 & .000 \\
Distributive & & & .135 & & 2.206 & .029 \\
Procedural & & & .652 & & 11.052 & .000 \\
Interactional & & & .101 & & 1.818 & .071 \\
Organizational climate & & & -.106 & & -1.971 & .050 \\
\hline
\end{tabular}

The result in table 3 showed that perceived organizational justice and organizational climate significantly and jointly influence job performance $[\mathrm{F}(4,181)=50.131, \mathrm{P}<.001$. the result further showed that perceived organizational justice and organizational climate jointly accounted for $54.1 \%$ of the total variance in job performance among secondary school teachers. Based on this finding, hypothesis three was confirmed.

\section{Discussion of Findings}

Hypothesis one was tested to find out if perceived organizational justice (distributive, procedural and interactional) will significantly influence job performance among secondary school teachers in Makurdi metropolis. This hypothesis was tested using simple linear regression and the result revealed that perceived organizational justice significantly influence job performance. This result further showed that, perceived organizational justice (distributive, procedural and interactional) significantly accounted for $51.8 \%$ of the total variance in job performance among secondary school teachers. On their individual contribution, it also revealed that, procedural justice made the highest contribution to the influence in job performance among secondary school teachers, distributive justice followed, while interactional justice did not make any significant contribution in the observed variance in job performance among secondary school teachers. Based on this finding, hypothesis one was only confirmed for distributive justice and procedural justice. The findings of this hypothesis is in agreement with the result of Salah, (2015) that found out 
a positive relationship for the organizational justice dimensions (distributive justice, procedural justice, interactional justice, evolutional justice) on worker performance, and worker satisfaction. The findings also agrees with that of Moosa, (2014) who found a positive relationship between organizational justice and its dimensions (distributive justice, procedural justice, informational justice) and job performance and its dimensions (context and obligation) and also there is a weak relationship between the above cases and procedural justice, so to promote employees' job performance in the area of organizational justice and its dimensions. Similarly Hasan, Ali and Al-Zu'bi, (2010) found a positive association between organizational justice and job performance.

Hypothesis two was tested to find out if organizational climate will significantly influence job performance among secondary school teachers was not significantly. The findings of this hypothesis did not agree with the result of Emeka, (2016) whose result revealed a positive correlation which was significant between the organizational climate and teacher's job performance, and there was also a positive correlationship, which was significant between the organizational climate and the teacher's job performances. Finding was also not in collaboration with that of Adeyemi, (2008) who revealed that; a significant relationship was however found between organisational climate and teachers' job performance.

Hypothesis three was tested to find out if perceived organizational justice and organizational climate will significantly and jointly influence job performance among secondary school teachers in Makurdi. This hypothesis was tested and the result showed that; perceived organizational justice and organizational climate significantly and jointly influence job performance. The result further showed that perceived organizational justice and organizational climate jointly accounted for $54.1 \%$ of the total variance in job performance among secondary school teachers. Based on this finding, hypothesis three was confirmed.

\section{Conclusion}

The study investigated the influence of perceived organisational justice and organisational climate on job performance among secondary school teachers in Makurdi. Three hypotheses were stated and tested. The result accepted hypothesis one, Hypothesis three and rejected hypothesis two. From the findings of the study, it is concluded that; perceived organizational justice significantly influence job performance among secondary school teachers in Makurdi and that that organizational climate did not significantly influence job performance among secondary school teachers in Makurdi metropolis, finally perceived organizational justice and organizational climate significantly and jointly influence job performance among secondary school teachers in Makurdi metropolis.

\section{Recommendations}

Based on the findings of the study, the following recommendations were made by the researcher:

i. The results of the study revealed that perceived organizational justice significantly influence job performance, therefore it is recommended that a new model of organizational justice with new implementation techniques should be conceded that can be implemented easily and successfully.

ii. The management of secondary schools should create an environment that is free for teachers being discriminated against. Based on the findings, it was recommended that head teachers should create a favourable climate to enhance better job performance among teachers.

iii. School management should always make effort to address the grievances of teachers to the performance of both the school and teachers.

iv. The government through the ministry of education should organise seminars to enlighten school management officials on the important roles played by perceived organisational justice that will enhance good job performance among teachers.

v. Teachers in secondary schools should be highly motivated (paying salaries on time, respecting their rights and opinions, etc.). This would reduce problems of workers turnover, lateness to work, increased loss of management among many others.

vi. None-governmental organisations should design packages that motivate teachers of secondary schools. These might include given them study scholarships, educating them and school management in order to avoid having a feeling of injustice. 
vii. Also, since the present study did not found any significant influence of organizational climate on job performance among secondary school teachers it is recommended that further study should be carried out to see other variables that are likely to be related to job performance.

\section{Limitation of the Study}

In conducting the research, some setbacks were encountered, one of which was the low number of sample and participants used for the research considering the entire population of secondary school teachers in Makurdi Benue State. Another setback was that of poor responses from participants, convincing participants towards participation was indeed a core challenge faced in the study. Time frame and financial constraints also served as militating factor to this research. Also, only perceived organization justice and organizational climate was used as independent variables in the study; further research should be carried out on other factors influencing job performance of secondary school teachers.

\section{References}

Adeyemi, T. O. (2008). Organizational climate and job performance among academic staff in primary schools in Ondo State, Nigeria. Journal of industrial psychology, 9(2), 62-87.

Alwan, F. (2007). The relationship between organizational Justice and organizational citizenship behaviors: Do fairness perceptions influence employee citizenship. Journal of Applied Psychology, 75. http://dx.doi.org/10.1037/0021-9010.76.6.845.

Ambrose, T., \& Schminke, J, (2009). The impact of organizational justice and personal characteristics on job performance: Afield study in the income tax department in Amman. The Jordanian Journal of Applied Sciences, $7(2), 1-15$.

Arabaci, I. B. (2010). Academic and administration personnel's perceptions of Organizational climate (Sample of educational faculty of Firat University): Procedia Social and Behavioural Sciences, 2, 4445-4450. https://doi.org/10.1016/j.sbspro.2010.03.709

Armstrong, T. Y., \& Baron, I. O. (2000). Fat-Bellied Monkeys Suggest Why Stress Sucks. Time. Retrieved 2009-08-08.

Arvey, S. K., \& Murphy, G. J. (2000). Hyperventilation Syndrome. Kyle Cathie Ltd.

Arvey, V.G., \& Murphy, T.W. (1998). Stress, Coping, and Development (2nd Ed.). New York: The Guilford Press.

Attaoa, P. S. (2002). Trust as a mediator of the relationship between organizational justice and work outcomes: test of a social exchange model. Journal of Organizational Behavior, 23(3), 267-285. https://doi.org/10.1002/job.138

Austin, Humphreys \& Hulin, (2004). Taming Stress. Scientific American, September 2003.

Baldwin, L. G., \& Baldwin, J. A. (1986). Personal and role-related factors in the development of organizational commitment. Administration science quartiles, 17, 555-573.

Ball, J., Trevino, C. J., \& Slim, M. A. (2000). Perceptions of inequity in the workplace: Exploring the link with unauthorised absenteeism. SA Journal of Human Resource Management, 10(1), 1-8.

Barling, J., \& Michelle, P. (2001). Interactional, formal and distributive justice in the workplace: An exploratory study. Journal of Psychology, 127(6), 649-656. https://doi.org/10.1080/00223980.1993.9914904

Barrett, B., \& Alexander, M. (2003). Taming Stress. Scientific American, September 2003.

Bartlett, H. L., \& Ghoshal, K. E. (2001). The Silent Denial of Stress in a Competitive World. 2012-03-17. Retrieved 2012-03-17.

Belling, M. N., \& Lounsbury, J. W. (2000). Openness and Job Performance in U.S. Academy of Management Journal, 14, 213-226.

Bies, R. J. (2001). International (in)justice: The sacred and the profane. In J. Greenberg \& R. Cropanzano (Eds.), Advances in organization justice (pp. 89-118). Palo Alto, CA: Stanford University Press.

Bies, R. J., \& Moag, J. F. (1986). Interactional justice: Communication criteria of fairness. In R. J. Lewicki, B. H. Sheppard, \& M. H. Bazerman (Eds.), Research on negotiations in organizations (Vol. 1, pp. 43-55). Greenwich, 
CT: JAI Press.

Borman, H.I., \& Motowidlo, N. (2004). Psychology the science of behaviour (4th ed.). Upper Saddle River, New Jersey: Pearson Education, Inc., 527.

Borman, T., \& Motowidlo, N. (2007). Effects of stress on the immune system. Immunology Today, 11(5), 170-175.

Brief, J. D., \& George, T. (1995). Prenatal Exposure to Maternal Depression and Cortisol Influences Infant Temperament. Journal of the American Academy of Child \& Adolescent Psychiatry, 46(6), 737.

Brief, J. D., \& Motowidlo, N. (2003). Marital distress prospectively predicts poorer cellular immune function. Psychoneuroendocrinology, 38(11), 2713-2719.

Campbell, J. (2000). Assessment of stress in patients with Recurrent Aphthous Stomatitis, by salivary alpha amylase using a Cocorometer" dissertation submitted for Oral Pathology to Maharashtra University of Health Sciences, Nashik. https://doi.org/10.1080/10253890701288935

Campbell, J. (2000). Evolution of concepts of stress. Stress: The International Journal on the Biology of Stress, 10(2), 109-120. https://doi.org/10.1080/10253890701288935

Campbell, J., Dunnette, M., Lawler, E., \& Weick, K. (2000). Managerial behaviour, performance, and effectiveness. New York: McGraw-Hill.

Cardy, V.L. (2000). Can Stress Take the Cost of Life. SSRN Electronic Journal.

Cardy, V.L. (2004). The Relaxation and Stress Reduction Work Book. New Harbinger inc.

Carson, J. (1969). Modeling Job Performance in A Population Of Jobs. Personnel Psy, 43(2), 313-575.

Cekmecelioglu, T.B. (2006). The degree of organizational justice among the heads of academic departments in the official Jordanian universities and their relationship allegiance organizational faculty members. Damascus University Journal, 25(1).

Celik, P.G, (2012). Analysis the relationship between organizational loyalty and the workers feelings with organizational justice. Administrative Magazine, 20(72).

Cherns, C. (1976). Organizational climate for innovation and creative teaching in urban and rural schools. Quality \& Quantity, 45(4), 935-951.

Cohen, R.L. (2000). Distributive Justice: Theory and Research. Social Justice Research, 1(1), 19-40. https://doi.org/10.1007/BF01049382

Cohen-Charash, Y., \& Spector, P. E. (2001). The Role of Justice in Organizations: A Meta Analysis. Organizational Behavior and Human Decision Processes, 86(2), 278-321. https://doi.org/10.1006/obhd.2001.2958

Colquitt, J., Greenberg, J., \& Zapata-Phelan. (2005). On the dimensionality of organizational justice: A construct validation of a measure. Journal of Applied Psychology, 86, 386-400. https://doi.org/10.1037/0021-9010.86.3.386

Creemers, J. B. (2000). The role of school and classroom climate in elementary school learning environments. In H.J. Freiberg (Ed.), School climate: Measuring, improving and sustaining healthy learning environments (pp. 30-48). London: Falmer Press.

Crino, P.T. (2003). Learned Helplessness: A Theory for the Age of Personal Control. New York: Oxford University

Cropanzano, R, \& Greenberg, J. G. (1997). Progress in organizational justice: Tunnelling through the maze. In C. L. cooper \& I. T. Roberson (Eds.), International review of industrial and organizational psychology, 12, 317-372. New York: John Wiley.

Cropanzano, R., \& Ambrose, M. L. (2001). Procedural and distributive justice are more similar than you think: A monistic perspective and a research agenda. In J. Greenberg \& R. Cropanzano (Eds.), Advances in organizational justice, pp. 119-151. Lexington, MA: New Lexington Press.

Cropanzano, R., \& Prehar, C. A. (1999, April). Using social exchange theory to distinguish procedural from interactional justice. Paper presented at the 14th Annual Conference of the Society for Industrial and Organizational Psychology, Atlanta, GA.

Cropanzano, R., Ambrose, M. L. \& Greenberg, J. (2007). Procedural and distributive justice are more similar than you think: A monistic perspective and a research agenda. In J. Greenberg \& R. Cropanzano (Eds.), Advances in organizational justice (pp. 119-151). Lexington, MA: New Lexington Press. 
Cropanzano, R., Prehar, C. A., \& Chen, P. Y. (2005). Using Social Exchange Theory to Distinguish Procedural from Interactional Justice. Group and Organization Management, 6(27), 324-351.

Dailey, R. C., \& Kirk, D. J. (1992). Distributive and procedural justice as antecedents of job dissatisfaction and intent to turnover. Human Relations, 45(3), 305-317. https://doi.org/10.1177/001872679204500306

Dawson, Abbott, \& Shoemaker. (2011). The hospitality culture scale: a measure organizational culture and personal attributes. Int J. Hospitality Mgt, 30(2), 290-300. https://doi.org/10.1016/j.ijhm.2010.10.002

Defrank, K.M. (2013). Psychological Stress and Disease (PDF). JAMA 298(14), 1685-1687. https://doi.org/10.1001/jama.298.14.1685. PMID 17925521.

Elanain, H. M. A. (2009). Testing the direct and indirect relationship between organizational justice and work outcomes in a non-Western context of the UAE. Journal of Management Development, 29(1), 5-27. https://doi.org/10.1108/02621711011009045.

Emeka, O. (2016). The relationship between organizational climate and employee satisfaction on job performance in Imo State. Journal of Industrial Psychology, 26, 513-563.

Faislat, A., \& Rasheed, O. (2013). Relationship between school climate and teacher job performance among secondary schools in Lagos State, Nigeria. Library Philosophy Practice, 9(2), 62-87.

Folger, R., \& Bies, R. J. (2005). Relative deprivation and referent cognitions: Distributive and procedural justice effects. Journal of Experimental Social Psychology, 22(6), 531-546. https://doi.org/10.1016/0022-1031(86)90049-1.

Folger, R., \& Cropanzano, R. (2001). Organizational justice and human resource management. Beverly Hills, CA: Sage.

Folger, R., \& Konovsky, M. A. (1989). Effects of procedural and distributive justice on reactions to pay raise decisions. Academy of Management Journal, 32(1), 115-130. https://doi.org/10.2307/256422.

Fried, (1991); Fried \& Ferris, (1987). Handbook of Stress Medicine. CRC Press.

Greenberg, J. (1986). Determinants of perceived fairness of performance evaluations. Journal of Applied Psychology, 71(2), 340-342. https://doi.org/10.1037/0021-9010.71.2.340.

Greenberg, J. (1990). Looking Fair Being Fair: managing Impressions of Organizational Justice. Research in Organizational Behaviour, 12, 57-111.

Greenberg, J. (1990b). Organizational justice: Yesterday, today, and tomorrow. Journal of Management, 16(2), 399-432. https://doi.org/10.1177/014920639001600208.

Greenberg, J. (1993a). The social side of fairness: Interpersonal and informational classes of organizational justice. In R. Cropanzano (Ed.), Justice in the workplace: Approaching fairness in human resource management (pp. 79-103). Hillsdale, NJ: Erlbaum.

Greenberg, J. (1993b). Stealing in the name of justice: Informational and interpersonal moderators of theft reactions to underpayment inequity. Organizational Behavior and Human Decision Processes, 54(1), 81-103. https://doi.org/10.1006/obhd.1993.1004.

Greenberg, J. G. (1978). Equity, motivation and effects of past reward on allocation decisions. Personality and Social Psychology Bulletin, 4, 131-134.

Greenberg, J. G. (1986). Determinants of perceived fairness of performance evaluations. Journal of Applied Psychology, 71, 340-42.

Greenberg, J. G. (1990). Organizational justice: Yesterday, today, and tomorrow. Journal of Management, 16, 399-432.

Greenberg, J. G., \& Colquitt, J. A. (2005). Handbook of organizational justice. New Jersey: Lawrence Erlbaum Associates, Publishers.

Greenberg, J. G., \& Leventhal, G. S. (1976). Equity and the use of over reward to motivate performance. Journal of Personality and Social Psychology, 34, 179- 190.

Greenberg, J., \& Baron, R. A. (2003). Behavior in organizations (8th ed.). Upper Saddle

Gurbuz, D. (2007). Justice in organizations: Theory, methods, and applications. In N. Anderson, D.S. Ones, H.K. Sinangil, \& C. Viswesvaran (Eds.), Handbook of industrial, work, and organizational psychology: Volume 2 
organizational psychology (pp. 143-165). Thousand Oaks, CA: Sage.

Guzzo, B., Jette, K., \& Katzell, A. E. (1985). On the etiology of climates. Personnel Psychology, 36, 19-39.

Hackman \& Oldham, (1976). Stress Management in Primary Care. Butterworth Heinemann.

Haritha, F., \& Subrahmanyam, N. (2013). Organizational Climate: An Empirical Investigation in Penna Cement Industries Limited. International Journal of Business and Management Invention, 2, 2319-8028.

Hasan Ali Al-zu'bi, M. (2010). Perceptions of organizational justice and job performance: A meta analysis. Journal of Organizational Behavior, 23(3), 257-266.

Hellriegel, D., \& Slocum, J. W. (2001). Organizational Behaviour in the Work Place. Journal of Social Behaviour and Personality, 51, 840-845.

Hersen, D.L. (2004). Coping and Stress: A Conceptual Analysis. Journal of Advanced Nursing, 45(6), 659-665.

Hersen, D.L. (2004). Multidisciplinary Approaches to Breathing Pattern Disorders. Churchill Livingstone.

Homans, G. C., \& Blau, P. M. (1977). A review of employee motivation theories and their implications for employee retention within organizations. The Journal of American Academy of Business, 31, 543-602

Horowitz, S. J. (1992). Commitment and Employee Behaviour. Work Employment and Society, 25(4), 794-205.

Ishak, H. (2009). Do it right this time: The role of employee service recovery performance in customer-perceived justice and customer loyalty after service failures. Journal of Applied Psychology, 92, 475-489.

Jamal, M. (2007). Relaxation Techniques: a Practical Handbook for Healthcare Professionals. Churchill Livingstone.

Jamal, P.F. (1985). Stress, stress reduction and hypercholesterolemia in African Americans: a review. Ethnicity \& Disease, 9, 451-462.

Jamal, T. (2007). Anthology of Stress Revisited: Selected Works Of James H. Humphrey. Foreword by Paul J. Rosch.Nova Science Publishers.p. viii. ISBN 9781594546402. Retrieved 2013-05-02.

Jawahar, I. M., Stone, T. H., \& Kisamore, J. L. (2007). Role conflict and burnout: The direct and moderating effects of political skill and perceived organizational support on burnout dimensions. International Journal of Stress Management, 14(2), 142-159.

Jex, B.Y. (2002). Conquer Your Stress. Chartered Institute of Personnel and Development.

Jex, B.Y. (2002). Hyperventilation Syndrome. Kyle Cathie Ltd.

Jing, S., Avery, W., \& Bergsteiner, U. (2011). Academic and administration personnel's perceptions of Organizational climate (Sample of educational faculty of Firat University): Procedia Social and Behavioural Sciences, 2, 4445-4450

Kallestad, G, (2010). Some of the personal characteristics of the Palestinian leadership and its relationship with some psychological and social variables. Unpublished Ph.D., Ain Shams University-Cairo.

Karsh, B., Bookse, H,Y., \& Sainfort, D. (2005). The extant of the employee satisfaction in the relief agency in Gaza about satisfaction on compensation and incentive systems. unpublished master thesis, Islamic University in Gaza.

Kessel, H., Hannemann-Weber \& Kratzer, R.T. (2012). Organizational Behaviour in the Work Place. Journal of Social Behaviour and Personality, 51, 840-845.

Konovsky, M. A. (2000). Perceived fairness of employee drug testing as a predictor of employee attitudes and job performance. Journal of Applied Psychology, 76(5), 698-707.

Kumar, H., \& Giri, J, (2007). The impact of the organizational justice and its relationship with organizational commitments: An empirical study on the Ministry of Higher Education and Scientific Research -Iraq. Journal of Tikrit Administrative and Economic Sciences, 8(24).

Leary, J. (1957). Innovative work behavior in healthcare: The benefit of operational guidelines in the treatment of rare diseases. Health Policy, 105, 146-153.

Lee, R. T., Griffin, J., Neal, B., \& Neale, S. (2007). Job burnout among nurses in Hong Kong: Implications for human resource practices and interventions. Asia Pacific Journal of Human Resources, 45(1), 63-84.

Lewin, K. (2001). Patterns of aggressive behaviour in experimentally created social climate. Journal of Social 
Psychology, 10, 271-290.

Litwin, G. H., \& Stringer, R.A. (2007). Motivation and organizational climate. Boston: Harvard Business School. Division of Research.

Loi, G., Borman, T., Ilgen, J., \& klimoski, K, (2006). Justice as a mediator of the relationship between the methods of control and organizational behavior citizenship. Strategic Management Journal, 11.

Masterson, T., Lewis, H.J., Goldman, E., \& Taylor, S. (2000). Relationships among pay inequity, perceptions of procedural justice, and organizational citizenship. Employee Responsibilities and Rights Journal, 8(1), 21-33. http://dx.doi.org/10.1007/BF02621253

Mbugua, C. (2009). Does organizational justice mediate the relationship between motivation and job performance of employees? African J. Business Mgt, 4(9), 1837-1843.

Meglino B.T. (1977). Does the perception that stress affects health matter? The association with health and mortality. Health Psychol, 31, 677-84. 2012. https://doi.org/10.1037/a0026743

Milkovich, K., Arnold, O., \& Ellen, T. (1991). Relationship of parental trauma exposure and ptsd to ptsd, depressive and anxiety disorders in offspring. Journal of Psychiatric Research, 35, 261-270.

Molm, L. (2005). Behaviourism: In George Ritzer (Ed.), Administration Science Quartiles, 19, 533-546. California: Thousand Oaks Sage.

Mooosa, H. (2014). Cultural differences in distributive and procedural justice: Does a two-factor model fit for Hong Kong employees? International Journal of Cross Cultural Management, 7(1), 61-76.

Murphy, M. (2005). Stress signalling pathways that impair prefrontal cortex structure and function. Nature Reviews Neuroscience, 10(6), 410-422.

Nelson, D. L., Smith, J. C., Greer, T. E., \& Duke, B. L. (2008). Preventive management of work stress: Current themes and future challenges. In A. Baum, T. A. Revenson, \& J. E. Singer (Eds.), Handbook of health psychology (pp. 349-364). Mahwah, NJ: Erlbaum.

Nicholson, E. A., \& Miljus, R. C. (1992). Job Satisfaction. New York: McGraw-Hill.

Nurharani, Y., Zahira, A., \& Shaminah, K. (2013). Relationships between job organization, and career commitments and work outcomes: An integrative approach. Organizational Behaviour and Human Performance, 26, 81-96.

Obeidi, G. C. (2012). Analysis of the dimensions of organizational justice: An empirical study. Cairo, Ain Shams University, Faculty of Commerce, Management Research magazine.

Pestonjee, D.M. (2009). Stress and Coping: The Indian Experience.

Pilo, C.M. (2013). Stress and Self Awareness: a Guide for Nurses. Heinemann.

Qureshi, J. J., \& Ramay, O. L. (2006). Stress-induced immune dysfunction: Implications for health. Immunology, 5(3): 243-251.

Rutherford, M. M. (2000). The role of environmental control on environmental satisfaction, communication, and psychological stress: effects of office ergonomics training. Environment and Behaviour, 36(1), 617-638.

Salah, S. (2015). The Role of organizational commitment in mediating the relationship between perceived organizational justice and job performance. European Journal of Social Sciences, 30(1), 125-135.

Sanson, B. (1975). Organizational climates: an essay. Personnel Psychology, 36, 19-36.

Schein, E. H. (1990). Organizational Psychology. New Jersey: Prentice-Hall Inc.

Serena, N. (2014). Health psychology: Developing biologically plausible models linking the social world and physical health. Annual Review of Psychology, 60, 501-524.

Storey, A. J. (2011). The relationship between. Organizational commitment and organization climate in manufacturing. Human Resource Development Quarterly, 15(4), 473-488

Sullivan, R.A. (1953). Determinants of innovative behavior: A path model of individual innovation in the workplace. The Academy of Management Journal, 37(3), 580-607. https://doi.org/10.2307/256701

Summer, J., \& Hyman, B.N. (2005). Confusion and controversy in the stress field. Journal of Human Stress 1(2), 37-44. https://doi.org/10.1080/0097840X.1975.9940406. PMID 1235113.

Tabibna, R., Sat Pute, K., \& Liberman, D. (2008). Justice perception in Medical Administrative Governance. 
International Journal of Business Research, 9(7), 147-155.

Tepper, B. J. (2000). Consequences of abusive supervision. Academy of Management Journal, 43(2), 176-190. https://doi.org/10.2307/1556375

Teprstra, B. J., \& Honoree, E. C. (2003). Relationships among supervisors and subordinates' procedural justice perceptions and organizational citizenship behaviors. The Academy of Management Journal, 46(1), 97-105.

Thurston, P. (2010). Clarifying the structure of justice using perceptions of performance appraisal processes. Paper presented at the 15th annual meeting of the Society for Industrial and Organizational Psychology. New Orleans, LA.

Thurston, S., \& McNall, P, (2010). Behaviour in organization understanding and managing the human side of work (3rd ed.). New York: McGraw -hill book Co.

Trist \& Bamforth. (1951). The Healing Mind: The Vital Links between Brain and Behaviour, Immunity and Disease. Thomas Dunne Books.

Tyler, T. R. (2005). Conditions leading to value-expressive effects in judgments of procedural justice: A test of four models. Journal of Personality and Social Psychology, 52(2), 333-344. https://doi.org/10.1037/0022-3514.52.2.333.

Tyler, T.R., \& Bies, R.J. (2004). Beyond Formal Procedures: the interpersonal context of Procedural justice, Carroll, J.S. Applied Social Psychology in Business Settings. (5th ed.). Hillsdale, NJ: Erlbaum, 77-98.

Unal, O. F. (2012). Relationship between Organizational Commitment Ethic Climate: The mediating role of Job Satisfaction dimensions (A study in a group of companies in Turkey). Journal of Wei Business and Economics, 1(1), 92-105.

Van Dyne et al. (1995). Stress and immunity: An integrated view of relationships between the brain and the immune system. Life Sciences, 44(26), 1995-2008. https://doi.org/10.1016/0024-3205(89)90345-7

Van Scotter, B., \& Motowidlo, N. (2006). Stress, Age, and Immune Function: Toward a Lifespan Approach. Journal of Behavioral Medicine, 29(4), 389-400. https://doi.org/10.1007/s10865-006-9057-4

Vroom, (1964). International handbook of human response to trauma. New York: Kluwer Academic/Plenum Press.

Vroom, V. H. (1964). Work and motivation. San Francisco, CA: Jossey-Bass.

Wall, B., \& Clegg, J. B. (1981). The organizational bases for ethical work climates. Administrative Science Quarterly, $333,101-125$.

Warner, J., Dunnette, J., \& Hough, P. (2005). Organizational Justice and Job satisfaction: A test of three Competing Models. Social Justice Research, 18(4), 391-409.

Wat, M., \& Shaffer, E.R. (2005). Toward and understanding of employment discrimination claiming: An integrating of organizational justice and social information processing theories. Personnel Psychology.,

Wiggins, A. K. (Eds.) (1991). Performance assessment for the workplace, Volume I. Washington, D.C.: National Academies Press.

Yilmaz, K., \& Tasdan, M. (2004). Organizational citizenship and organizational justice in Turkish primary schools. Journal of Educational Administration, 47(1), 108-126. https://doi.org/10.1108/09578230910928106.

Yong-ki Chi \& Sally, Hun. (2015). Behaviour in organization understanding and managing the human side of work(3rd ed.).New York: McGraw -hill book Co. 